\title{
THE REPRESENTATION OF INDONESIAN WOMEN IN CONTEMPORARY TRAVEL WRITING: A STUDY OF DISCOURSE ON GENDER AND TRAVEL WRITING
}

\author{
Akmal Jaya', Mochamad Rizqi Adhi Pratama² \\ ${ }^{1}$ Japanese Literature Department, Faculty of Law and Humanities, \\ Universitas Ngudi Waluyo \\ ${ }^{2}$ English Literature Department, Faculty of Law and Humanities, \\ Universitas Ngudi Waluyo \\ Email: akmaljaya@unw.ac.id, rizqi.adhi@unw.ac.id
}

\begin{abstract}
This research aims to examine the representation of Indonesian women in contemporary travel writings. The rise of globalization has challenged the domination of discourses that tend to place Indonesian women in the subordinate position. However, the challenge does not warrant a symmetrical relation between genders, as it sometimes blurs the relation as a result of clashes between discourses. This study, then, provides an overview of how discourses have shaped the representation of Indonesian women by revealing images that appear explicitly and implicitly in travel stories. Using the Foucauldian discourse analysis approach allowed the writers to exclude subjects, objects, and meanings to discover a comprehensive web of image construction. This research found that Indonesian women's representation is stuck in an ambiguous position as it strives to be an independent individual subject.
\end{abstract}

Keywords: Indonesian women, gender, travel writing, discourse, representation

\begin{abstract}
ABSTRAK
Penelitian ini bertujuan untuk menjelaskan representasi perempuan Indonesia melalui cerita perjalanan kontemporer. Pada dasarnya, globalisasi telah menantang kuasa hegemoni wacana yang cenderung menempatkan perempuan Indonesia pada posisi kedua. Akan tetapi, hal tersebut tidak menjamin kesetaraan antara hubungan gender, melainkan terkadang menjadikannya semakin kabur sebagai konsekuensi adanya pertentangan antar wacana. Kajian ini memberikan gambaran bagaimana wacana membentuk representasi perempuan Indonesia dengan menunjukkan citra-citra yang hadir secara eksplisit maupun implisit dalam cerita perjalanan. Dengan menggunakan pendekatan analisis Foucauldian memberikan sebuah kemungkinan kepada kita untuk memisahkan antara subjek, objek dan makna dan untuk menemukan jaring-jaring konstruksi citra yang komprehensif. Penelitian ini menemukan bahwa representasi perempuan Indonesia terjebak dalam posisi yang ambigu yang tampaknya mencoba untuk hadir sebagai subjek independen.
\end{abstract}

Keywords: Perempuan Indonesia, gender, cerita perjalanan, wacana 


\section{INTRODUCTION}

Discussions on gender are unlikely to reach any final conclusion soon since awareness of equality and the efforts to ease domination come and go. Some social movements by feminists persist in spaces previously dominated by the masculine power. In Indonesia, gender inequality is not as simple as what happens in, for example, European countries. A heterogeneous society may present a complexity in which one community holds a belief that overlaps with what other societies that exist alongside it view as the truth. For instance, the people of the Minangkabau ethnic group adhere to a matriarchal system, while the Bugis recognize five genders in their social system. This condition supports the view that gender relations are not universal, but instead have their own uniqueness and each requires a distinct approach to understand it.

The struggle for gender equality then sneaks into every corner of literary narrative. Unsurprisingly, literature has long become an alternative medium for different groups to voice their resistance. As stated by Kaplan, literature is part of the political process of resistance, rejection, which is part of women's work (via LeBihan, 2001: 103). In line with this statement, Registes states that literary works are also used as material for women's freedom movements and to disseminate feminist ideas (Registes via Stimpson, 1981: 234).

One genre of literature that emphasizes these attitudes is travel writing. Although it is one of the colonial period's cultural artefacts, the last decade has actually seen a rapid increase of travel stories written by Indonesians about Europe. The phenomenon indirectly awakens the colonial memory of the colonizer and the colonized within the scope of globalization. However, studies of travel stories in relation to colonialism tend to focus on the colonial aspect.

Since the 1970s, travel stories have grabbed the attention of feminists to fight against imperial societal conventions that position adventure activities within the framework of masculinity. However, current studies on women travel story writers tend to revolve around European women. That being the case, studies on adventures of Indonesian women experiencing oppression both historically (through colonization) and culturally (through patriarchy) still call for deeper scrutiny. Therefore, this study focuses on female Indonesian adventurers and their representation in contemporary travel stories through various discourse contexts.

Different studies on gender problems in Indonesia have been carried out. However, those researches are limited to certain contexts. Studies on Indonesian women generally focus on women's roles and their relationship with a series of discourses that have contributed to how women are positioned in the social conditions of Indonesian society. These discourses include traditional values, religion, colonialism, and the state. This series of discourses is considered to have shackled the role of women in the public sphere and emphasized the domestic space instead (Arimbi, 2009; Biezeveld, 2007; Blackburn, 2004, 2008; Blackwood, 2008; Bünte \& Ufen, 2008; Drakeley, 2005; Florida, 1996; Ford \& Parker, 2008; Forshee, 2006; Hatley, 1995, 1999; Martyn, 2005; Pompe, 1994; Robinson, 2008; Taylor, 2009; Woodward, 2011).

The globalization era has seen travel story as an example of how space is created to distinguish between being home (domestic) and being away (public). This implies that, first, traveling refers to moving from one place to another, an activity that has historically been dominated by men, while staying at home is reserved for women. This has indirectly led to traveling being associated with masculinity, legitimized by a patriarchal culture (Bassnett, 2007; Kuehn \& Smethurst, 2008; Lisle, 2006; Mills, 1993; Muzakka, 2020; Smith, 2001; Thompson, 2011). Second, in Indonesia, writers of women's travel stories deal with a set of social series of discourses about other worlds: themselves and their colonial history. Therefore, this research aims to explore the representation of Indonesian women constructed by a series of discourses in travel stories.

This research hypothesizes that the power of discourse negotiated by Indonesian female authors tended to be ambiguous, antagonistic, and ambivalent. The scientific questions compiled are: What is the discourse of women in every political period in Indonesia? What possibilities do travel stories offer for a shift in the representation of women?

This research seeks to determine the extent of the shift in the discourse of women in Indonesian society, and how being a travel writer or adventurer has given women new perspectives in introducing and redefining women's role in Indonesia. 
Experts have widely studied travel stories and their connection to gender issues. However, those studies tend to pay more attention to the travel stories of European women. Some of those studies are:

Daniela Kato, Two women travellers across a contested landscape: Emily Georgiana Kemp and Yosano Akiko in Northeast China (2018), comparing two travel stories about East China written by Emily Georgiana Kemp, The Face of Manchuria, Korea and Russian Turkestan (1911), and Yosano Akiko, Travels in Manchuria and Mongolia (1928). In her writing, Kato distinguishes between ethics of encounters and the aesthetics of cultural differences through an interdisciplinary approach, starting from verbal to representational, and finds that the differences and changes occur in the field of encounters.

Several articles cover stories of the journey of European women in the colonies. One article by Laurence Williams, "Like the ladies of Europe"? Female emancipation and the "scale of civilization" in women's writing on Japan, 1840-1880 (2017), explores the rhetorical shifts found in a book titled Unbeaten Tracks in Japan (1880) by Isabella Lucy Bird, which tells the lives and social levels of Japanese women. Through intertextuality analysis, Williams shows that these texts shed light on various political problems of the Victorian Era: women's education, divorce, property rights, and prostitution. Likewise, a study conducted by Ana Stevenson, Harriet Clisby's 'Sketches of Australia': travel writing and colonial refigurations in Boston's Woman's Journal (2018), examines the construction of discourse on Australian colonial society in a transnational context.

Apart from postcolonial issues, gender studies and travel writings also reveal the reception of one work by another, as seen in Laura Loth's Writing and Traveling in Colonial Algeria after Isabelle Eberhardt: Henriette Celarié's French (Cross) Dressing (2017). The article reveals the complex legacy of Henriette Celarie's travel imagination. Loth focuses on how Celarie combines her imagination with the legend of Eberhardt as a new element, which not only deconstructs but also supports traditional understandings of gender and culture found in the stories of women's travel in the late 19th century. Likewise, Pam Perkins's “News From Scotland": Female Networks in the Travel Narratives of Elizabeth Isabella Spence (2017) explores the net of influence that Elizabeth Isabella Spence had on other female writers. Furthermore, the article also reveals that Spence's Letters from the North Highlands, during the Summer 1816 (1817) created an extraordinarily centric feminism in the Scottish romantic era.

Naked Traveler (2014) and The Jilbab Traveler (2009), two works that are the objects of this research, have also been studied by several researchers. A thesis by Brigita Tubun Kumoratih, Indonesian Women Travellers' Experiences and Challenges in The Naked Traveler Anthology (2017) discusses the experiences and challenges that become the stereotypes for female Indonesian travel story writers. Kumoratih found that Naked Traveler reinforces the stereotype of women travellers' activities being dominated by shopping. Moreover, Rudi Ekasiswanto's Depictions of the World in Trinity's The Naked Traveler: 1 Year Round-TheWorld Trip (2017) discusses how the depiction of the world in Naked Traveler using the Carl Thompson method. The study found that the depiction of the world tends to be subjective.

An article titled "Isi Pesan Dakwah Aqidah dan Syariah Dalam Film Indonesia Islami "Jilbab Traveler: Love Sparks In Korea" (2019) by Masturina Khoirun Nisa et al delves into the values of Islamic law as presented in Asma Nadia's work. Using Ferdinand de Saussure's theory of semiotics, the study found how Islamic rituals are summarized within the work in certain signs.

Having mentioned all of the works above, this research aims for novelty in its attempt to reveal the representation of Indonesian women in contemporary travel stories. Therefore, it is clear how this research contributes to the field. First, it enriches the studies on female travel story writers, many of whom tend to focus on European women. Second, to find the position of Indonesian women not only in the text but also indirectly in the outside world that they visit.

\section{THEORY AND RESEARCH METHOD}

This research was conducted by combining various interdisciplinary and theoretical studies: travel writing, postcolonialism, and gender studies. This research also presents various kinds of discourses that shape the subjectivity of Indonesian women as writers and sheds light on the various areas where they are examined. The objects of this research are The Naked Traveler: 1 Year Round The World Trip by Trinity (2016a) and The Jilbab Traveler by Asma Nadia (2016). 


\section{On Discourse}

According to Foucault, discourse can refer to any statement or expression made that has meaning and effect. The statement or expression can be in the form of grouping; such as a more general topic or idea like masculinity, so the statement or expression is not only a written text or a string of spoken words but also everything related to the topic. Therefore, Foucault emphasizes that discourse is not the text (statement or expression) by itself but rather how the text is produced to form the discourse (Michael Foucault, 1972 :91).

Discourse, however, is not left unchecked; some play a role in controlling it, and some exercise the control altogether. Predictably, discourse is often associated with power - it has the power to oppress as well as to fight. As one looks at the relationship between discourse and reality, it is not as simple as equating it with language. It involves a system that shapes how reality is seen, because a word or a sentence is not associated with what is known (certain knowledge), but rather what limits and what is perceived.

Discourse is perpetuated through the principle of regularity, "a practice which we impose on [things]; and it is in this practice that the events of discourse find the principle of their regularity... Thus, the regularities which we perceive in realities should be seen as the result of anonymous regularities of discourse we impose on reality" (Mills, 1993: 56). The regularity referred to here is in the form of prohibition. As Foucault observes, the discourse production procedure is through exclusion, which is in the form of prohibition (Faruk, 2012: 242). The procedure includes three kinds of external exclusion, namely: "taboo, the difference between mad and sane, and the distinction between true and false" (Mills, 1993: 57-58), also referred to as objective prohibitions, subjective prohibitions, and contextual prohibitions (Faruk, 2012: 242).

The three kinds of external exclusion create the process of how discourse exists in society. For example, let's say an object becomes taboo, which limits the way people know what they know. Then, not everyone can talk about certain things - a limitation that pertains to the exclusive rights of the subject. One example for this is a mentally unwell person; what he or she says will not be considered. The third limitation exists within the scope of right and wrong (contextual) prohibitions, which are common in rituals. For this type of prohibitions, as Foucault puts it, power sees the "expert" distinguish "the right" from "the wrong", and "the truth" is materially supported by various practices and institutions (Mills, 1993: 58). As such, someone's statement is considered true if it is appropriate or fits with other statements that society deems valid.

Foucault also asserts that there are four internal procedures of exclusion. These are commentary, the author, disciplines, and the rarefaction of the speaking subject. These procedures are all concerned with classifying, distributing, and ordering discourse. Their function is ultimately to distinguish between those who are authorized to speak and those who are not - those discourses which are authorized and those which are not. The first internal exclusion, commentary, is writing about another's statements. Thus, literary criticism can be considered to be commentary. (Mills, 1993: 58-9)

As mentioned in the above quotation, the four internal principles of exclusion procedure also have the same function, namely to control and to limit discourse. Such principles are needed because the discourses themselves exercise control (Faruk, 2012: 244). As an example, a certain text is commented on and discussed because it is more interesting and therefore more appreciated than a group of other texts. The role of the commentary or comment is to say what is in the text for it to be modified, retold, and repeated. Then a new discourse emerges and makes itself known in a more current setting, rendering the text infinitely transformed and the process repeated. The comment keeps the discourse in circulation, giving it the same function and principle as continuous modifications (Faruk, 2012: 245; Mills, 1993: 59).

The second principle takes place through the author. What is meant by the author here is not the individual speaking or writing the text, but rather the one grouping the discourse. As an example, a certain author produces many books, and when read one after the other it becomes apparent that one text is a reaction to the other. Although in the end the author may be attributed, many discourses that are not derived from the author are attributed to the 
discourse. For example, in the quote below:

Foucault is very critical of such notions as the progression of an author from immaturity, early works to maturity, or later works. If we discuss the 'early' works of Shakespeare, we should interrogate why it is that we are using such a metaphor, implying as it does that these works are less developed than his later texts, and we should simply analyze these texts in their terms, rather than according to a fictional scheme which we have of Shakespeare's life. (Mills, 1993: 60)

An author is asked to take into account the unity of the text as a representation of his/her life in order to reveal hidden meanings in their work, linking the work to the author's experience or real history that led to the birth of the work. The author thus becomes a point of coherence and an entry into reality.

The next principle of internal exclusion is discipline. This limitation is placed upon the subject matter or the thing discussed. A discipline must allow for the formulation of new statements, holding what is said to be right or wrong, the limits of the disciplinary rules themselves, and this is where the principle of limitation lies (Faruk, 2012: 247). Through a certain set of methods and approaches, a text has been limited to discussing only certain things under a set of methods and approaches; because the discipline has a set of propositions and rules that are considered factual to produce new propositions or new statements about what is true or false. The last principle of internal exclusion is the rarefaction among speaking subjects. What is meant is the limitation on who has the right to speak; some discourses are open to everyone and some are limited.

From the procedure of producing discourse both externally and internally, it can be understood that not all discourse is open to everyone. Restrictions in the form of certain prohibitions or regulations differentiate between right and wrong, and all these existing procedures keep the discourse in circulation - retold, transmitted, modified, distributed - in a particular society. Speech ritual, discourse society, doctrine, and social appropriation are interrelated and form a large type of education that ensures the distribution of speaking subjects into different types of discourse (Faruk, 2012: 250).

In essence, discourse can be seen as a term that refers to statements, the rules that are formed from these statements, and through the process by which these statements are circulated and other statements are excluded.

Thus, discourses should be seen as groups of statements that are associated with institutions, which are authorized in some sense and which have some unity of function at a fundamental level. The statement can be seen as an authorized proposition or action through speech. (Mills, 2003: 65)

Furthermore, Dreyfus and Rabinov gave more emphasis on the statements referring to discourse.

The statement is not simply a sentence because, for example, a map or image could be taken as a statement. The critics, Hubert Dreyfus and Paul Rabinow, argue that 'Maps can be statements if they are representations of a geographical area, and even a picture of the layout of a typewriter keyboard can be a statement if it appears in a manual or as a representation of the way the letters of a keyboard are standardly arranged' (Dreyfus and Rabinov in Mills, 2003: 65).

The discourse, which is a group of statements on the same topic, also has the same effect, which is possible because of institutional pressure or association with certain institutions. Empirical data for this research were collected through the observation method, namely careful, rigorous, and thorough reading to find data. There are two variables used: dependent and independent variables. The dependent variable is in the form of textual units, sentences, and paragraphs containing elements of subjectivity, genre, memory, and geography. The independent variable in the intertextual units includes a series of discourses about the identity of Indonesian women, which is related to representation in external, historical, sociological, or political texts. After the collection stage, the data are then classified/grouped in a binary/hierarchical opposition relationship to one another. That way, we can get an overview of the differences/similarities of strategies, colonialism, postcolonialism, to globalization.

For Data Analysis, the data that has been classified into certain categories are then analyzed and criticized using the method of critical discourse analysis by Michel Foucault. This method uses several 
principles. The first principle is The Inversion, which is a strategy to find forms of exclusion, restriction, and power authority. The second principle is The Discontinuity, namely a strategy that specifically relates to external texts (Foucault, 1981: 70). These principles are intertwined with one another, which serves to reveal how discourse is produced, distributed, and managed in society. Mills reveals how the webs of discourse correlate with power. In this case, discourse is understood as an organized system that can construct our perspective in seeing the world (Mills, 2005: 55). In other words, humans are controlled by the power of discourse. Even so, the power of discourse is never absolute. It will always create spaces of resistance and the emergence of counter-discourses (Michel Foucault, 1978).

\section{RESULTS AND DISCUSSION}

\section{Discourses on Indonesian Women and Travel Stories}

Discourse is believed to have the power to shape characters and ideas. However, individuals also have the authority to escape the power of discourse. These two things are reflected in travel stories that sometimes show contestations between discourses and how the subject responds to this.

\section{Discourses on Indonesian Women}

It is important to understand how the discourse on the identity of Indonesian women has developed from each period. This is to ensure that changes or developments are never perfect, allowing opportunities for other discourses to exist.

Let us begin with customs, or the various traditional laws across Indonesia with their different ideas about gender (Drakeley, 2005; Pompe, 1994:111). Early visitors and western observers of Indonesia noted the relatively high status enjoyed by women with quite varied social and economic roles in farming and trade (Lamoroux, 2003: 131). Nevertheless, some archetypal modes regarding sexes across Indonesia showed the tendency for women to be represented as weak (Biezeveld, 2007; Forshee, 2006; Nilam \& Utari, 2008), more emotional, and less intelligent than men (Arimbi, 2009: 57). On the other hand, myths pervaded the islands of women as terrible or dangerous figures (Forshee, 2006: 160), and traditional literature also has women depicted as lost spirits who forget their "normal" roles (Sylvia, 1998: 60).

The arrival of Islam brought the concept of women's nature as being God-given. It became a popular doctrine and ideology throughout the archipelago, establishing the belief that the ideal women belonged to the domestic sphere, and defined their role, based on their physical and mental qualities, to be less competent than men (Biezeveld, 2007: 207). Their biological, reproductive capacities make tending the hearth, caring for the children, serving their husband, and to be chaste and submissive as expected of them (Arimbi, 2009; Blackburn, 2004; Robinson, 2008; Woodward, 2011).

Indonesia experienced an influx of Western views of gender via the colonial system as Dutch rule spread across the archipelago from the seventeenth century onwards (Blackburn, 2004; Ricklefs, 1993). In 1901, the colonial government established the ethical policy in the colony. One of the policy's concerns emphasized the role of Javanese women in the household and, in relation to this, their position in the labor market (Blackburn, 2004; Lamoroux, 2003). Furthermore, the role of housewife was not only encouraged by the Dutch through the establishment of numerous vakscholen (vocational school), which taught European housewifely skills to women who were not peasants nor aristocrats (Tiwon, 1999: 58), but also by Christian missionaries who tried to impose Western family norms on local households and to convince indigenous women that their most important roles were as a housewife and a mother (Meerkerk, 2017: 50). During the Japanese occupation, Fujinkai, a wives' organization of military characteristics was formed. It emphasized the primary roles of women as wives and mothers who should offer loyal support to their husbands who were joining the military force under the regime (Blackburn 2004: 21).

In 1945, Indonesia became an independent state. Soekarno, one of Indonesia's founding fathers, who was strongly influenced by Western socialist and democratic views, helped establish the early version of The 1945 Constitution, in which gender relations tend to focus on efforts to strengthen the new republic, along with its mention that all citizens hold equal standing before the law. This in turn encouraged the formation of nationalistic women's organizations (Blackburn 2004: 21-23). The most 
noticeable women's organization during Soekarno's regime was Gerakan Wanita Indonesia (Gerwani, or the Indonesian Women's Movement), established in 1950, a left-wing, radical women's organization affiliated with Partai Komunis Indonesia (PKI, or Communist Party of Indonesia) which promoted women's emancipation (Hatley 1999: 452, Dutt and Robinson 2008: 121, Blackburn 2004: 23, Robinson 2008: 55, Tiwon 1999: 39, Hatley 1995: 452). The flourishing of women's organizations up until this point shows that the idea of the ideal woman gradually changed and that the public-domestic dichotomy for Indonesian women was blurred.

However, under Indonesia's next president Soeharto, who ruled from 1967 until 1998, the state gender ideology of State Ibuism (or simply Ibuism; ibu means "mother" in Indonesian) was adopted. It described a woman as an appendage to the husband and promoted female dependency as ideal (Suryakusuma 1999: 98, Robinson 2008: 189). As an ideology of gender relation, Ibuism reinvented what had been conceived to be traditional or religious gender roles (kodrat wanita, or women's natural tendencies), restricting women's capacity to organize independently to pursue their interests, social participation, and political activities in the public sphere and emphasized their roles as mothers and wives in the domestic sphere (Drakeley 2005: 127, Robinson 2008: 10, Hatley 1995: 574, Nilan and Utari 2008: 137, Blackburn 2004: 24-25, Tiwon 1999: 25, Forshee 2006: 44). This image was in part based on the Western middle-class ideal, the Javanese priyayi culture, as well as Islam which had influenced government policies in Indonesia since earlier times (Biezeveld: 207, Robinson 2008: 189). The notion of kodrat wanita was institutionalized in Dharma Wanita (Women's Service), the association of wives of civil servants, which introduced Panca Dharma Wanita the five duties of women - that all of its members had to perform in order to be seen as the ideal Indonesian women, namely to support the husband, to manage the household, to bear children, to be a social worker, and to be a loyal citizen (Taylor 2013: 166, Nyman 2009: 255, Robinson 2008: 5, Sunindyo 1999: 124125, Blackwood 2008: 18).

\section{Globalization and Conflicts between Discourses}

Since the fall of the New Order through the 1998 reform movement, public spaces have become more open and democratic. One progress has seen freedom of expression as an influential tool in allowing people to pour anything out of their minds without the fear that dominated the preceding period. Among the aspects that have received special attention is the freedom to choose one's own gender and sexual orientation. Despite constant resistance from conservative groups, this development is clear evidence of a major cultural shift in the Indonesian society (Udasmoro, 2017).

Of all the themes related to this development, travel stories appeared to be among the most interesting ones. Here we have two activities: going out on adventures or trips and telling stories. Both globalization and the reform era have played their part in the development of this theme. Globalization provides various kinds of motivation to travel (Lisle, 2006; Urry, 1990), which goes hand in hand with the phenomena of internationalization, liberalization, universalization, and digitization (Scholte, 2005; Strange, 1996). In addition, freedom of expression as an internal factor has allowed travelers to go to various regions and to write down the experience. The two factors make the boundaries of differences, both regional and cultural, increasingly fluid and flexible.

\section{Jilbab vs. Naked}

The increasingly blurred boundaries of differences, of course, have its consequences that arise from the contestation between existing discourses. This condition is reflected in two stories about journeys made by two Indonesian women, The Jilbab Traveler and Naked Traveler. Each story carries its own ideology, one being the opposite of the other. The jilbab (headscarf) is often associated with the obedience of the Muslim woman who observes the religious order to cover herself; the more of herself that she covers, the more obedient, respectable, and dignified she is. However, different associations also emerge from the veil, namely conservatism, fundamentalism, and close-mindedness. On the contrary, the word naked can easily be interpreted as without clothes, bare, and exposed, an interpretation that can lead to negative connotations when juxtaposed with the word woman, such as undignified, lacking control, disobedient, and even immoral.

The presence of the jilbab in Indonesia is thought to have started in the $15^{\text {th }}$ century, brought along by scholars who had studied in the Arabian 
Peninsula. Around that time, the headscarf was merely a piece of cloth that still revealed the women's hair and neck. Global politics is considered to have played a major part in the changing shapes of the jilbab in Indonesia. Ripples of The Iranian Revolution and the ideology of the Muslim Brotherhood in the 1970s slipped into Indonesian campuses, and the headscarf became a symbol of the revival of the true Islamic missionary movement. Consequently, during the New Order period, women with a closed head scarf were often associated with certain sects.

\section{Travel Writing (Men vs. Women)}

The fall of the New Order gave way to space for mutual contestation between the two forces, including in the genre of travel stories. There are at least three major discourses related to this genre. The first is how travel stories underline masculinity. Second, the veil, bound by a strong discourse of religiosity, seems to go hand in hand with the discourse of patriarchy. Finally, we have the liberal discourse and how it is reinforced by feminist ideas.

The discourse on the genre of travel stories is packed in such a way with masculine elements that seem impossible for women to meet. The first element is leaving or being away from home. Travel has been seen as masculine in this way since ancient humans divided their roles based on different physical abilities, namely hunting for men and staying at home taking care of the children for women. This division of roles has indirectly led to the division of areas of authority, with the masculine covering the external sphere and the feminine reigning over the internal/ domestic sphere. This condition spills over into the second element, namely the destination - a foreign, perilous land which forces the physical aspects to once again play an important role through expectations of strength, courage, and heroism. The last element is the authority of truth in the telling of one's experiences in those unfamiliar, perilous lands. This last aspect also distinguishes the spaces of authority between the masculine and the feminine into public and private spaces. Male adventurers were given the right to publish their stories to be consumed by the general public. In contrast, the women were limited to diaries and personal letters.

\section{The Jilbab Traveler vs. Naked Traveler}

The emergence of travel stories Naked Traveler and
The Jilbab Traveler provides evidence that there is resistance to the hegemony of the travel story discourse in the way they carry their respective discourses. First, both respond to the discourse of patriarchy, and second, the discourse of colonialism. The question, however, is how far the two works respond to the hegemony of the travel story genre.

Naked Traveler offers one woman's phenomenal travel stories that were published as a series and have been adapted into a film. One cannot mention this success without mentioning the writer's strategy in grabbing the reader's attention. It begins with the apparently naughty and provocative word in the title. The choice of the word naked (without clothes) implies the quality of being clearly visible or not hidden, as well as open and vulnerable. When attached to adult humans, both male and female, the same word may suggest negative connotations that make way for controversy. Such controversy often raises the issue of power imbalance as it is usually the woman who is forcefully subjected to social norms: the nakedness of a woman, thrown in the open, makes her dishonorable, undignified, wild, uneducated, and blasphemous, more so than when compared with her male counterpart.

Concurrently, the connotations that arise as a consequence of choosing the word implicitly show a form of resistance toward the construction of discourse on how Indonesian women are bound by existing norms. The belief that a woman must maintain honor, show manners, and behave appropriately is stripped away by the choice of the word naked. In other words, the writer places women in the position of the subject, as opposed to the prevailing view that women are objects that are susceptible to assessment. In this new position, women gain freedom of authority to manage their bodies according to their ideology.

Naked Traveler represents women's freedom, independence, and courage through the exploration of other countries. To that, The Jilbab Traveler arrives as a response to the implicit message sent by its opposition. This notion is explicitly expressed in a passage in The Jilbab Traveler:

Because traveling should not be the same for Muslim women, especially those donning a headscarf, as for other women. It's sad to read travel books that spread liberalism when travel should really bring us closer to God. (p.vii) 
This statement presents the notion that women's struggles against the discourse of masculinity in travel stories are not homogeneous; there are variations in how women respond to the hegemony.

In their own ways, both works reflect an effort to achieve equal standing in the field of travel stories. However, one must inquire: To what extent does the consistency of these two works stand independently against the strong hegemony within the travel story discourse?

\section{Power of Discourse and Representation of Indonesian Women}

Discourse and representation are two contexts that are bound by the causality of causality. In other words, representation does not exist alone and free of value but is shackled to the prevailing discourse. Lisle reveals that representation is not as simple activity as write-read-interpret, but rather a political activity that involves a network of power created by writers, readers, and the world that they are living in (Lisle, 2006). Nevertheless, referring to Foucault, the power of discourse naturally creates efforts of resistance to the hegemony of discourse itself. These two things describe how the circulation of discourse is managed through external factors (subjectification), namely the norms that determine how a person acts to recognize himself and be recognized by others; and the internal factor (subjection) as a consciousness that enables the shift of norm.

From this paradigm, the representation of women in Naked Traveler and The Jilbab Traveler dwells on the web of discourse on the relationship between the travel story genre and Indonesian women. The two discourses are not singular but are related to other discourses, such as the relationship between the travel story genre and masculinity or colonialism. Meanwhile, the discourse on Indonesian women is related to religion, customs/traditions, and the state, which often legitimizes each other, but at the same time also overlaps.

\section{The Power of Genre Discourse}

Structuralist Treztan Todorov outlines the basic principles of the travel story genre: a). travel stories are about journeys, b). they are composed using a narrative story, c). they are works of nonfiction, $d$. they employ fictional elements, f). they are about (encountering) differences (Lisle, 2006). These six principles seem to be realized in the two travel stories analyzed in this article, Naked Traveler and The Jilbab Traveler.

The two novels recount the adventures of the writers in other countries, are arranged in a narrative method (beginning-middle-end), are based on true stories but use fictional elements in the description of the things that they encounter, and they reveal the differences between self (identity) with others (the people they meet).

To Lisle, the principles offered by Todorov fail to explain the discourses that surround the travel story genre. Some of these discourses include discourses on modern subjectivity, on modern mapping, and on nostalgia which are centered on a logical system of differences that constructs various kinds of representation that arise in the travel stories. Such differences include the distinction between the author and the written text, between the idea of being home and being away, and between the past and the present.

In Naked Traveler, Trinity, the adventurer, follows the standard plot of the travel story. From the beginning, the writer refers to herself as an adventurer and a backpacker, distinguishing herself from tourists. This distinction suggests the extent of independence an adventurer has in an unfamiliar territory; adventurers decide which unfamiliar destinations they want to go to, and what they are going to do there, while tourists usually book their trips through a travel agency and have the itineraries set up for them.

Unlike Trinity, Jilbab Traveler provides different motives for the travels made in the novel, from studying abroad, accompanying the husband on official trips, to working trips or assignments. The difference of context has implications for the forms of the journeys made, as the journeys that the writer make do not fall into the category of travels commonly found in the travel story genre. The novel simply focuses on the activities of moving from one place to another, not on the experiences learnt from the series of trips.

\section{The Power of Modern Subjectivity Discourse}

The distinction between the forms of travel made in the two travel stories also has implications for the types of journey involved. As an adventurer, 
Naked Traveler's Trinity explores areas unspoiled by the tourism industry. Tourists visit the mostvisited tourist attractions, while the adventurer in Trinity brings her to destinations easily overlooked by tourists. In the book, she chooses destinations Indonesians have rarely visited.

Second, many have never set foot on the South American continent. For this reason, I traveled with a "new" concept and published the story in a book. (Trinity, 2016b: ix).

A selection of destinations that many of the readers have not visited gives the adventurer at least three privileges. Being "the first to be there" was a strategy heavily employed in past European adventure stories. During that period, access to information and knowledge about foreign lands was limited to those who set out and roamed the seas. For the first privilege, as seen in Trinity's reflection in the above quotation, the position of being "the first to be there" gives the author more flexibility to manage how she should introduce the readers to all the mysteries enshrouding the foreign territory. This flexibility allows Trinity to make the most of the scary, challenging, and entertaining elements of her stories, a benefit referred to by Trinity in the book as first-mover advantage, borrowing the marketing strategy jargon.

What appears in Trinity that distinguishes her from tourists - from choice of destinations to style of travel - shows the power of modern subjectivity discourse in relation to the discourse on masculinity. The author's voice is expected to always give the impression of bravery, eliminating all sorts of feminine qualities such as fear and timidity. Lisle calls the phenomenon the birth of a new identity, becoming part of the honorary men, in which case a female adventurer shows the characteristics expected by the travel story genre from her male counterpart (Lisle, 2006: 95).

While Trinity is shackled to masculine ideals, the writer of The Jilbab Traveler is trapped in an ambivalence. On the one hand, The Jilbab Traveler tries to break away from the jilbab stereotype, namely a woman confined by strict religious rules. On the other hand, however, the author legitimizes it by rejecting the principles of freedom itself.

The subject in The Jilbab Traveler is what is known as the new men, a condition in which the writer-adventurer resists the oppression that they are experiencing, which can be either colonial or patriarchal. This identity is considered to be the biological child of cosmopolitan values. However, in this story, the commitment to resistance is not unchanging, as it seems to depend on whether or not it is in line with the author's interests.

These symptoms are present in several travel moments in The Jilbab Traveler, either through actions or explicit statements. They are reminders that the more religous concept of the Muslim woman comes with the segregation of not only spaces (certain rooms associated with women such as inside their homes, in the kitchen, in the bedroom, etc.) but also duties and responsibilities between women and men. Travel then becomes a major content for the writer, as she offers it to the readers to show that a woman's veil can "spread its wings", a metaphor for freedom. However, the journeys are never completely liberating, as the author/main character sometimes journeys with her husband, or makes a trip while pregnant, or travels with her child (Nadia, 2016, p. 118; 120; 190). In other words, the journeys remains within the grips of the discourse on women's nature.

\section{The Power of Modern Cartography Discourse}

Positioning Naked Traveler and The Jilbab Traveler in the middle of the travel story genre and the discourse on masculinity, it is not adequate to simply differentiate the authors from one another; there needs to be distinctions between the objects that they write about. In this case, it is how the two subjects respond to the entire sets of differences that they encounter in foreign countries. This is important because, in the process of differentiation, the values that are embedded in the cultures and the historical aspects of the authors serve as reference in measuring the differences that they come across.

Naked Traveler reviews those differences in a straightforward manner. The selection of destinations that have rarely been visited by Indonesians gives her a high level of flexibility in sharing her findings, such as the things she discovers on her travels to Latin American countries. In Colombia, Trinity presents her stories with a sense of adventure and a tinge of suspense, as she talks about the country's status as one of the world's largest drug producers, about 
cases of tourists being kidnapped, about corruption and high crime rates, all the way to the theory it is the most dangerous country in the world (6-20).

\section{The Power of Nostalgic Discourse}

One of the characteristics of the authoritative quality possessed by an author is that not only are they able to explore current conditions, but are also able to collect traces of the past and present them to the readers in a compelling manner. The presence of the past is evoked by elements of ancient culture, such as things that are strange, mystical, and primordial. Some of these things can be found in Naked Traveler as the author tells of her journey in Colombia, when she comes across a Cuban "gadget freak" community, and the inadequate means of transportation she has to endure when in Guatemala (Trinity, 2016a).

Both authors claim that their travels are no ordinary travels. Trinity seems to have the privilege to claim that her choice of destination is unlike most Indonesian tourists, while Nadia's destination choices are based on her spiritual calling, hence the other label: the pilgrim traveler. The later has implications in her choice of diction when visiting areas that happen to be dominated by the aspect of religiosity, such as: getting closer to Allah (p:vii); by Allah's permission (p:6); destiny (p:78); and to marvel at God Almighty's creation (p:157). The heavy use of spiritual elements in this work is not extraordinary, as it can be found in many earlier travel stories as a form of response to Western culture and a way to carry Eastern values across.

Even though spirituality dominates in The Jilbab Traveler, that does not make it free from tensions as they arise from the author's encounters with differences. Several representations of the other suggest unequal oppositional relations, including violent Arab societies (p:42); the disgruntled Iranian society (p:46); the barbaric Syrian community (p: 47); how Albanian immigrants are a source of problems ( $p: 109) ;$ and concerns regarding black people (p:239). Different images are portrayed when author meets with Europeans, such as the Danes, the happiest people on earth (p:97) and the tolerant society of UK (p:162).

The above representations imply the existence of inequality that travelers find between the West and the East. In this case, the two cultures are placed in opposition to each other. The West tends to be described as superior to the East, both culturally and physically. This depiction also shows the hegemony of the discourse of Orientalism, where the author's position is subject to Western domination in assessing other civilizations.

The dynamics between representations of different societies as found in The Jilbab Traveler indicates a fragile and split subject, as can be seen from its overlapping efforts. This contradiction can be seen in the way how the travellers reveal themselves. First, travel activities are carried out as a way to deconstruct the exclusivity of women wearing headscarves trapped in ambivalent conditions. The adventurer never really travels as an independent subject but is still attached to be dependent subject. Second, the author fails to use the Eastern discourse as a counter-discourse to Western hegemony, and instead legitimizes the power of Western discourse by repeating the values of Orientalism.

\section{CONCLUSION}

The representation of women in the two works, Naked Traveler and The Jilbab Traveler, reflects the contestation of discourses on women in Indonesia. First, the notion that Indonesian women are weak is challenged by these two writings. Both The Jilbab Traveler and Naked Traveler offer new narratives about women as adventurers, a role previously dominated by masculinity.

The participation of women in the realm of men in the context of adventure indirectly shows a shift in how women are viewed in society. Of course, the influence of globalization is controlled by the principles of liberalism and equality.

The concept of liberalism has divided the two directions of the Indonesian women's movements. This becomes the second point of discourse contestation, namely in how they attempt to show the freedom of the female subject but through different concepts. Trinity is trapped by the demands for gender equality that has been formulated by European feminists through the travel story genre.

The Jilbab Traveler expresses freedom based on the inherent values of women's fashion. Hence, instead of demanding gender equality between masculine and feminine, The Jilbab Traveler proclaims equality between veiled and non-veiled women. Therefore, in the course of ibuism, the discourse on women's nature 
is still strong, even reiterated and legitimized.

Third, the pressure of the travel story genre discourse on women also affects women's representation. In this case, the genre forces the female adventurer to appear bold, become the subject of authority, and negate the other. In The Jilbab Traveler, for example, even though the author often give negative labels toward the other, she is not exempted from racist treatments, which make her feel inferior at the same time.

Something similar can be found in Naked Traveler, whose author decides to visit South America just because she wants to be seen different from tourists. This choice shows nothing but the strength of genre discourse that separates travel writing from travel books, which demands an element of novelty in the story.

Fourth, discourse contestation ends in the representation of women who are trapped in ambiguous positions. The discourse of adventure, liberalism, and the travel story genre simultaneously creates other meanings. The adventures carried out by these two stories are made as if they were traveling to a foreign place, but in essence, this is not the case. In The Jilbab Traveler, the traveler does not leave her domestic space at all, which is confined by the rules of religious dogma as a wife and a mother. This condition can be understood as a displacement within same space.

As for the Naked Traveler who carries the spirit of European feminism, she also fails to escape from the traps of dominant discourses. Her efforts to pioneer the adventures of Indonesian women to South America have indirectly confirmed the dichotomy of modern cartographic discourse, one that divides areas into safe and dangerous, civilized and uncivilized.

These four things render the representation of Indonesian women blurred, vulnerable, and not fully intact. On the one hand, it shows an independent and equal side of women, but on the other hand, it is still oppressed by a series of dominant discourses.

\section{ACKNOWLEDGMENTS}

Thank you to the Ministry of Research, Technology, and Higher Education 2019 for the Early Researcher Grant (PDP) 2020.

\section{REFERENCES}

Arimbi, D. A. (2009). Reading Contemporary Indonesian Muslim Women Writers : Representation, Identity and Religion of Muslim Women in Indonesian Fiction. https://doi.org/10.5117/9789089640895

Bassnett, S. (2007). Travel writing and gender. In The Cambridge Companion to Travel Writing. https:// doi.org/10.1017/ccol052178140x.014

Biezeveld, R. (2007). The many roles of adat in West Sumatra. In The Revival of Tradition in Indonesian Politics: The Deployment of Adat from Colonialism to Indigenism. https://doi. org/10.4324/9780203965498

Blackburn, S. (2004). Women and the state in modern Indonesia. In Women and the State in Modern Indonesia. https://doi.org/10.1017/ CB09780511492198

Blackburn, S. (2008). Indonesian women and political Islam. Journal of Southeast Asian Studies. https:// doi.org/10.1017/S0022463408000040

Blackwood, E. (2008). Not your average housewife: Minangkabau women rice farmers in West Sumatra. In Women and Work in Indonesia. https://doi.org/10.4324/9780203932360

Bünte, M., \& Ufen, A. (2008). Democratization in post-Suharto Indonesia. In Democratization in Post-Suharto Indonesia. https://doi. org/10.4324/9780203934760

Drakeley, S. (2005). The History of Indonesia. In The Greenwood histories of the modern nations,

Ekasiswanto, R. (2017). Penggambaran Dunia dalam The Naked Traveler 1 Year Round-The-World Trip Karya Trinity. SEMIOTIKA: Jurnal Ilmu Sastra Dan Linguistik. https://doi.org/10.19184/semiotika. v18i1.5182

Faruk. (2012). Metode Penelitian Sastra: Sebuah Penjelajahan Awal. Pustaka Pelajar.

Florida, N. K. (1996). Sex Wars. In Fantasizing the Feminine in Indonesia (pp. 207-224). Duke University Press. https://doi.org/10.1215/9780822396710-009

Ford, M., \& Parker, L. (2008). Women and work in Indonesia. In Women and Work in Indonesia. https://doi.org/10.4324/9780203932360

Forshee, J. (2006). Culture and Customs of Indonesia. In Ebook.

Foucault, Michael. (1972). The Archaeology of Knowledge \& The discourse on Language. In The Archeology of Knowledge and the Discourse on Language. https://doi.org/10.1002/9780470776407.ch20

Foucault, Michel. (1978). The History of Sexuality, Volume 1: An Introduction. The History of Sexuality An Introduction, I, 168. https://doi. org/10.2307/1904618 
Foucault, Michel. (1981). The Order of Discourse. In R. Young (Ed.), Untying the Text: A Post-Structuralist Reader. Routledge \& Kegan Paul ltd.

Hatley, B. (1995). Women in contemporary Indonesian theatre; Issues of representation and participation. Bijdragen Tot de Taal-, Land-En Volkenkunde / Journal of the Humanities and Social Sciences of Southeast Asia. https://doi. org/10.1163/22134379-90003029

Hatley, B. (1999). New directions in Indonesian women's writing? the novel saman. Asian Studies Review. https://doi.org/10.1080/10357829908713250

Kato, D. (2018). Two women travellers across a contested landscape: Emily Georgiana Kemp and Yosano Akiko in Northeast China. Studies in Travel Writing. https://doi.org/10.1080/13645145.20 18.1493816

Khoirun Nisa, M., Ana Fardila, U., \& Widodo, A. (2019). Isi Pesan Dakwah Aqidah Dan Syariah Dalam Film Indonesia Islami "Jilbab Traveler Love Sparks in Korea”. Translitera : Jurnal Kajian Komunikasi Dan Studi Media. https://doi.org/10.35457/ translitera.v8i01.594

Kuehn, J., \& Smethurst, P. (2008). Travel writing, form, and empire: The poetics and politics of mobility. In Travel Writing, Form, and Empire: The Poetics and Politics of Mobility. https://doi. org/10.4324/9780203890974

KUMORATIH, B. T. (2017). Indonesian Women Travelers' experiences and Challenges in The Naked Traveler Anthology. http://repository.unika.ac.id/15032/

Lamoroux, F. (2003). Cover-image not available. ABCCLIO, Inc.

LeBihan, J. (2001). Feminism and Literature. In S. Gamble (Ed.), Feminism and Postfeminism. Routledge Companion.

Lisle, D. (2006). The Global Politics of Contemporary Travel Writing. In Cambrigde University Press (1st ed.). Cambridge University. https://doi. org/10.1017/CB09780511491535

Loth, L. (2017). Writing and traveling in colonial Algeria after isabelle eberhardt: Henriette Celarié's French (Cross) Dressing. In Tulsa Studies in Womens Literature. https://doi.org/10.1353/ tsw.2017.0018

Martyn, E. (2005). The Women's Movement in Postcolonial Indonesia. In The Women's Movement in Post-colonial Indonesia. https://doi. org/10.4324/9780203299197

Meerkerk, E. van N. (2017). Unravelling the impact of colonial connections of both Javanese and Dutch women's work and household labour relations, c. 1830-1940. Tijdshcrift Voor Genderstudies, 20(1),
35-59.

Mills, S. (1993). Discourses of difference: An analysis of women's travel writing and colonialism. https:// doi.org/10.4324/9780203379882

Mills, S. (2005). Michel Foucault. Routledge.

Muzakka, M. (2020). The Gender Equality Struggles in The Novel of Perempuan Berkalung Sorban and Gadis Pantai. Jurnal Ilmu Sastra, 8(2). https://doi. org/10.22146/poetika.60528

Nadia, A. (2016). The Jilbab Traveler. Asma Nadia Publishing House.

Nilam, P., \& Utari, P. (2008). Meanings of work for female media and communication workers. In M. Ford \& L. Parker (Eds.), Women and Work in Indonesia. Routledge. https://doi. org/10.4324/9780203932360

Perkins, P. (2017). ???News from Scotland???: Female Networks in the Travel Narratives of Elizabeth Isabella Spence. Women's Writing. https://doi.or g/10.1080/09699082.2016.1207910

Pompe, S. (1994). Between crime and custom; Extramarital sex in modern Indonesian law. Bijdragen Tot de Taal-, Land-En Volkenkunde / Journal of the Humanities and Social Sciences of Southeast Asia. https://doi.org/10.1163/22134379-90003095

Ricklefs, M. C. (1993). A History of Modern Indonesia since c. 1300. https://doi.org/10.1007/978-1349-22700-6

Robinson, K. (2009). Gender, Islam and democracy in Indonesia. In Gender, Islam and Democracy in Indonesia. Routledge. https://doi. org/10.4324/9780203891759

Scholte, J. A. (2005). Globalization: A Critical Introduction. Palgrave MacMillan.

Smith, S. (2001). Moving Lives Twentieth-Century: Twentieth-Century Women's Travel Writing. University of Minnesota Press.

Stevenson, A. (2018). Harriet Clisby's 'Sketches of Australia': Travel writing and colonial refigurations in Boston's Woman's journal. Women's History Review. https://doi.org/10.10 80/09612025.2017.1403094

Stimpson, C. R. (1981). On Feminist Criticism. In P. Hernadi (Ed.), What is Criticism. Indiana University Press.

Strange, S. (1996). The Retreat of The States. Cambrigde University Press.

Taylor, J. G. (2009). The social world of Batavia: Europeans and Eurasians in colonial Indonesia: Second edition. Univ of Wisconsin Press.

Thompson, C. (2011). Travel Writing. Routledge.

Tiwon, S. (1999). Model and Maniacs: Articulating The Female in Indonesia. In L. J. Sears (Ed.), 
Fantasizing the Feminine in Indonesia. https:// doi.org/10.2307/2760861

Trinity. (2016a). The Naked Traveler: 1 Year Round The World Trip Part 1. Bentang Pustaka.

Trinity. (2016b). The Naked Traveler: 1 Year Round The World Trip Part 1 \&amp; 2. Bentang Pustaka.

Udasmoro, W. (2017). Women and The Reproduction of Literary Narratives In The Construction of Nation. LITERA. https://doi.org/10.21831/ltr. v16i2.17411
Urry, J. (1990). The Tourist Gaze. Leisure and Travel in Contemporary Societies. Sage Publishing.

Williams, L. (2017). "Like the ladies of Europe"? Female emancipation and the "scale of civilisation" in women's writing on Japan, 1840-1880. Studies in Travel Writing. https://doi.org/10.1080/136 45145.2017.1301007

Woodward, M. (2011). Java, Indonesia and Islam. In Java, Indonesia and Islam. https://doi. org/10.1007/978-94-007-0056-7 